\title{
DIAGNOSTIC DIFFICULTIES IN PATIENTS WITH JUVENILE MYOCLONIC EPILEPSY
}

\author{
Haki Cemile, ${ }^{1}$ Akdogan Ozlem, ${ }^{2}$ Bora İbrahim Hakk1 ${ }^{3}$ \\ ${ }^{1}$ Department of Neurology, Bursa City Hospital, Bursa, Turkey \\ ${ }^{2}$ Department of Neurology, Istanbul Training and Research Hospital, Istanbul, Turkey \\ ${ }^{3}$ Department of Neurology, Uludağ University Faculty of Medicine, Bursa, Turkey
}

Primljen/Received 23. 07. 2020. god.

Abstract: Objective: In this study, we aim to share the data of patients who were followed-up and treated with a diagnosis of juvenile myoclonic epilepsy (JME), and to draw attention to the difficulties in diagnosis and the problems that may occur in treatment.

Method: In this study, seizure types, demographic and EEG characteristics of 75 patients with JME were retrospectively analyzed in our tertiary care center.

Results: Of the total 75 cases, 48 patients (64\%) were female and 27 patients $(36 \%)$ were male. The overall female/male ratio was $1.7 / 1$. The age of onset of seizures ranged from 6 to 24 years old. According to seizure types, all patients had myoclonic seizures, 65 patients $(86 \%)$ had generalized tonic clonic seizures and 17 patients $(22.6 \%)$ had absence seizures. Of the cases, 13 patients $(17.3 \%)$ had febrile convulsions, 4 patients $(5.3 \%)$ had a history of febrile convulsions in their families and 10 patients $(13.3 \%)$ had a family history of epilepsy. For 63 (84\%) patients, seizures were under control with valproic acid alone. When the patients EEGs were examined, 55 patients $(73.3 \%)$ had generalized epileptiform activity, 11 patients $(14.7 \%)$ had focal abnormaly and 9 patients (12\%) had no abnormality. It was determined that the diagnosis of JME was not established at the onset of the disease and the seizures were not under control for $40 \%$ of the patients who were admitted to our outpatient clinic from different centers.

Conclusion: Physicians should be very careful in the diagnosis of JME and the presence of myoclonia and absence seizures should be questioned in all patients presenting with generalized tonic-clonic seizures between 8-20 years of age in polyclinic practice.

Key Words: Juvenile myoclonic epilepsy, diagnosis, Idiopathic generalized epilepsy.
Prihvaćen/Accepted 14. 11. 2020. god.

\section{INTRODUCTION}

Juvenile myoclonic epilepsy (JME) is one of the widely occurring idiopathic generalized epilepsies. Its characteristic triad consists of myoclonic jerks, generalized tonic-clonic seizures (GTCS) and absence seizures. Seizures usually begin during adolescence or young adulthood $(1,2)$. The first known JME was defined in 1867 (3). Although most patients with JME benefit from valproate monotherapy, they require life-long treatment since they are likely to relapse if medications are discontinued $(4,5)$.

Studies have reported a delay in diagnosis in patients with JME and the possibility of missing the diagnosis even for patients evaluated by a neurologist (6, 7). Although it is a generalized epilepsy, focal EEG features and unilateral and asymmetric myoclonic jerks can be interpreted as focal seizures and this condition may lead to misdiagnosis and inappropriate treatment $(8,9)$.

In this study, the clinical and electrophysiological data of patients followed-up with a diagnosis of JME in a tertiary care center were examined. In this study, we aim to draw attention to the difficulties that may arise in the diagnosis of JME.

\section{MATERIAL AND METHODS}

Our study was a retrospective study with a total of 75 patients with a diagnosis of JME who were followed-up and treated in Epilepsy Outpatient Clinic of Uludag University Faculty of Medicine. Approval for the study was obtained from the Ethics Committee of the Bursa Yuksek Ihtisas Training and Research Hospital. All procedures performed in study were in accordance with the ethical standards of the institutional research committee and with the Helsinki declaration. 
Patients with mental retardation and children under 6 years old were excluded from the study.

Demographic characteristics, neurological examination findings, seizure onset age, seizure types, cranial imaging and interictal EEG characteristics, antiepileptic treatments, history of febrile convulsions and family history of epilepsy were evaluated retrospectively. EEG features (normal, generalized or focal abnormalities) and recently used antiepileptic drug treatments were recorded. It was noted whether the patients responded to the antiepileptic treatment or not. For the diagnosis of epilepsy, the International League Against Epilepsy (ILAE) classification criteria (10) were used.

At least two interictal EEG activity tests during wakefulness for all patients were performed. EEGs were measured on an 21-channel EEG device (Nihon Kohden, Neurofax 2) for 30 minutes, according to the international 10-20 system, in which standard activation methods were used. Cranial magnetic resonance imaging (MRI) imaging was performed with a $1.5 \mathrm{~T}$ device (Magnetom Vision Plus, Siemens, Erlangen, Germany).

\section{Statistical Analysis}

The data indicated that the descriptive statistics corresponded to a normal distribution and are given as mean and standard deviation. For non-compliance with normal distribution, data are expressed as median (minimum: maximum) and average.

\section{RESULTS}

Of the total 75 cases, 48 patients $(64 \%)$ were female, $27(36 \%)$ were patients male. The overall female/male ratio was $1,7 / 1$. The mean age of the patients was $14.31 \pm 4.93$. It was determined that all patients had myoclonic seizures, $65(86 \%)$ of the patients had GTCS and 17 patients (22.6\%) had absence seizures. When the patients were assessed in terms of seizure combinations, it was observed that 8 patients $(10.6 \%)$ of them had only myoclonic seizure, 50 patients $(66.6 \%)$ had myoclonic and GTCS, 2 patients $(2.6 \%)$ had myoclonic and absence seizure, and 15 patients $(20 \%)$ had myoclonic seizure, GTCS and absence seizures (Table 1).

Fifty-five (73.3\%) of the patients had 3-6 Hz spike and polyspike-wave discharges on interictal EEG, while $11(14.7 \%)$ had only focal discharges. However, no abnormality was found in the EEG in $9(12 \%)$ of the patients. The neuroimaging method for all patients was cranial MRI. One patient had cavum septum pellucidum, 1 patient had right hippocampal atrophy, 1 patient had asymmetric enlargement in the right lateral
Table 1. Demographic and clinical data

\begin{tabular}{|l|c|c|}
\hline \multicolumn{3}{|c|}{$\begin{array}{c}\text { Demographic and clinical data } \\
\text { of a total of 75 patients }\end{array}$} \\
\hline Value & Percentage \\
\hline Gender & 27 & $36 \%$ \\
\hline Male & 48 & $64 \%$ \\
\hline Female & & \\
\hline Seizure types & 75 & $100 \%$ \\
\hline Myoclonic seizure & 65 & $86 \%$ \\
\hline GTCS & 17 & $22.6 \%$ \\
\hline Absence seizures & 8 & $10.6 \%$ \\
\hline Only myoclonic seizure & 50 & $66.6 \%$ \\
\hline Myoclonic + GTCS & 15 & $20 \%$ \\
\hline Myoclonic + GTCS + absence & 2 & $2.6 \%$ \\
\hline Myoclonic seizure+absence & & \\
\hline EEG Findings & 55 & $73.3 \%$ \\
\hline Generalized & 11 & $14.7 \%$ \\
\hline Focal & 9 & $12 \%$ \\
\hline Normal & & \\
\hline Antiepileptic treatment & 12 & $16 \%$ \\
\hline Single drug & & \\
\hline Double drug use & & \\
\hline & & \\
\hline
\end{tabular}

ventricle, and 1 patient had venous angioma in the right precentral gyrus. Cranial MRI examinations of the other patients were normal.

In the analysis of their medical and family histories was presented that 13 patients $(17.3 \%)$ had febrile convulsions, 4 patients $(5.3 \%)$ had febrile convulsions in the family and 10 patients $(13 \%)$ had a family history of epilepsy. It was observed that seizures were provoked with insomnia in $6(8 \%)$ of the patients. In 63 $(84 \%)$ of the cases, seizures were kept under control with only valproic acid. In twelve $(16 \%)$ patients, another drug was added to the valproic acid treatment (lamotrigine to 11, clonazepam to 1) (Table 1). Age of onset for valproic acid was 19.2 years old on average.

In $40 \%$ of the patients who applied to our outpatient clinic from external centers, JME was not diagnosed at the beginning of the disease and appropriate antiepileptic treatment was not applied to the patients. In 30 patients who were not diagnosed with JME when they applied to our center, the average time until the correct diagnosis was 4 years. Due to the continuation of seizures despite the antiepileptic treatment in these patients, JME was diagnosed after reviewing their histories again. 


\section{DISCUSSION}

The prevalence of JME among all epilepsies is $5-10 \%$. Usually the first seizures between 12 and 18 years of age are well recognized $(11,12)$. There are many studies showing female dominance for JME (13, $14,15)$. In our study, in accordance with the literature, $48(64 \%)$ of the patients were female, 27 patients (36\%) were male and the female-male ratio was 1.7/1.

Although myoclonic seizures are the most common seizure type in patients with JME, absence seizures and generalized tonic clonic seizures are also observed, and in a small number of patients, myoclonic seizures occur alone $(16,17)$. While all of our patients had myoclonic seizures, only $20 \%$ had all three of myoclonic, absence and generalized tonic clonic seizures. In $10.6 \%$ of our patients, only myoclonic seizures were observed. Especially in patients with only myoclonic seizures, the diagnosis of JME may be overlooked unless in doubt. Especially unilateral myoclonic seizures may be misleading in the diagnosis of JME.

Although 3-6 Hz spike-slow wave activity is conventionally observed on EEG in patients with JME (16), comparatively high rates of focal EEG findings can also be observed. (18) The rate of observing asymmetric localizations and / or patterns on EEG may approach $50 \%$ (17). The rate of focal findings on EEG in our patients was compatible with the literature (19). In our study, generalized epileptiform activity was present in $55(73.3 \%)$ of the patients and focal anomaly was present in $11(14.7 \%)$ patients. EEG of nine patients was found to be normal. Since the frequency of epileptic anomaly may increase especially in sleep-deprived EEG imaging, EEG with sleep deprivation should be performed in cases with normal EEG.

JME is an inherited disorder. It was found that $40 \%$ of JME patients had epilepsy in their families, and $75 \%$ of them had epilepsy in a first degree relative (20). In the studies, the prevalence of familial epilepsy in patients with JME was $28 \%-43 \%(6,7,21)$. In our study, we found this rate to be $13 \%$.

It is controversial whether febrile convulsions are a risk factor in idiopathic generalized epilepsies (IGE), including JME. Some studies, febrile convulsions have been found to be associated with poor prognosis in JME (22). In the studies conducted, the frequency of febrile convulsion history in JME patients is determined as $11-14 \%(7,22)$. In the patients in the current study, we observed that 13 patients $(17.3 \%)$ had febrile convulsion history, 4 patients $(5.3 \%)$ had febrile convulsions in the family.

Patients with juvenile myoclonic epilepsy have a good response to valproate monotherapy (4). Due to the side effects of valproic acid, the European Medici- nes Agency (EMA) warned against the use of valproic acid in girls with epilepsy and it recommended the use of other treatments for women of childbearing age (23). However, $60 \%$ of female patients receiving valproic acid therapy were reported not to support stopping valproic acid therapy because of other antiepileptic drugs have failed or did not intend to become pregnant (24). In our study, seizures were controlled by valproic acid therapy in $84 \%$ of patients, and a secondary drug was added to valproic acid therapy in $12(16 \%)$ patients.

In a study performed in Turkey, it was stated that misdiagnosis is seen in $52.6 \%$ of JME patients (6). In a second study after seventeen years, it was observed that the rate of misdiagnosis had decreased to $24.5 \%$. This situation has been attributed to an increase in awareness and experience with the disease in Turkey (7).

In all general tonic-clonic seizures (GTCS) occurring during adolescence, JME should be considered primarily as a diagnosis (25). In $40 \%$ of patients who applied to our outpatient clinic from external centers, JME was not diagnosed at the beginning of the disease. When the anamnesis of these patients was evaluated in detail in our center, the patients were diagnosed with JME.

\section{CONCLUSION}

Insufficiency in the diagnosis of JME is a serious medical mistake. Because of the difficulties in the diagnosis of JME, clinicians can stigmatize patients as clumsy and they may increase seizure frequency with inappropriate antiepileptic drugs.

In clinical practice, the possibility of myoclonic seizures should be kept in mind in cases of incompetence in motor behavior that the patients or their relatives call clumsiness. The history of myoclonus should be questioned in all patients presenting with seizures, including GTCS, especially in patients aged between 8-20 years old, and JME should be considered as a preliminary diagnosis.

\section{Acknowledgement}

This study was approved by Bursa Yuksek Ihtisas Training and Research Hospital with the decision numbered 2011-KAEK-25 2019 / 12-10

Conflict of Interests: The authors declare that there are no conflicts of interest related to this article.

Funding: None

\section{Licensing}

This work is licensed under a Creative Commons Attribution 4.0 International (CC BY 4.0) License. 


\title{
Sažetak
}

\section{DIJAGNOSTIČKE TEŠKOĆE KOD PACIJENATA SA JUVENILNOM MIOKLONIČNOM EPILEPSIJOM}

\author{
Haki Cemile, ${ }^{1}$ Akdogan Ozlem, ${ }^{2}$ Bora İbrahim Hakk1 ${ }^{3}$ \\ ${ }^{1}$ Department of Neurology, Bursa City Hospital, Bursa, Turkey \\ 2 Department of Neurology, Istanbul Training and Research Hospital, Istanbul, Turkey \\ ${ }^{3}$ Department of Neurology, Uludağ University Faculty of Medicine, Bursa, Turkey
}

Uvod: Cilj ove studije je da se prikažu podaci pacijenata koji su praćeni i lečeni od juvenilne mioklonične epilepsije, i da se skrene pažnja na teškoće u dijagnozi i probleme koji se mogu javiti u lečenju.

Metod: Studijom je obuvaćeno 75 pacijenata sa JME. Tipovi napada, demografske karakteristike i EEG karakteristike su retrospektivno analizirani u našoj tercijarnoj zdravstvenoj ustanovi.

Rezultati: Od ukupno 75, 48 pacijenata (64\%) je bilo ženskog pola I 27 (36\%) muškog. Odnos između polova ženski/muški 1,7/1. Godine starosti u kojima su se napadi počeli javljati kreću se od 6 do 24 godine. Prema tipu napada, svi pacijenti su imali mioklonične napade, 65 pacijenata $(86 \%)$ je imalo generalizovane tonično klonične napade i 17 pacijenata $(22,6 \%)$ absens napade. Od ukupnog broja pacijenata, $13(17,3 \%)$ je imalo febrilne konvulzije, 4 pacijenta $(5,3 \%)$ je imalo istoriju febrilnih konvulzija u svojim porodicama i

\section{REFERENCES}

1. Dreifuss FE. Juvenile myoclonic epilepsy: characteristics of a primary generalized epilepsy.Epilepsia. 1989; 30(Suppl. 4): S1-7; discussion S24 7.

2. Nordli DR Jr. Idiopathic generalized epilepsies recognized by the International League Against Epilepsy. Epilepsia. 2005; 46 (Suppl 9): 48-56.

3. Eadie MJ. The epileptology of Theodore Herpin (1799 1865). Epilepsia. 2002; 43(10): 1256-61.

4. Chowdhury A, Brodie MJ. Pharmacological outcomes in juvenile myoclonic epilepsy: Support for sodium valproate. Epilepsy Res. 2016; 119: 62-6.

5. Stevelink R, Koeleman BPC, Sander JW, Jansen FE, Braun KPJ. Refractory juvenile myoclonic epilepsy: a meta-analysis of prevalence and risk factors. Eur J Neurol. 2019; 26(6): 856-64.

6. Atakli D, Sozuer D, Atay T, Baybas S, Arpaci B. Misdiagnosis and treatment in juvenile myoclonic epilepsy. Seizure. 1998; 7(1): 63-6.

7. Atakli D, Senadim S, Baslo SA, Güveli BT, Daryan MD, Sari H. Misdiagnosis in JME: still a problem after 17 years ? Seizure. 2016; 36: 27-30.

8. Fernandez-Baca Vaca G, Park JT. Focal EEG abnormalities and focal ictal semiology in generalized epilepsy. Seizure. 2020;77:7-14. doi: 10.1016/j.seizure.2019.12.013. Epub 2019 Dec 20.

9. Elmali AD, Auvin S, Bast T, Rubboli G, Koutroumanidis M. How to diagnose and classify idiopathic (genetic) generalized epilepsies. Epileptic Disorders.2020; 22(4): 399-420.
$10(13,3 \%)$ pacijenata je imalo pozitivnu porodičnu anamnezu u smislu epilepsije. Kod 63 (84\%) pacijenata napadi su bili pod kontrolom samo sa valproičnom kiselinom. Nakon pregleda EEG-a, kod 55 (73,3\%) pacijenata je nađena generalizovana epileptiformna aktivnost, $11(14,7 \%)$ pacijenata je imalo fokalne abnormalnosti I 9 (12\%) je imalo uredan nalaz. Utvrđeno je da se dijagnoza JME nije postavila nakon pojave bolesti i napadi nisu bili pod kontrolom kod $40 \%$ pacijenata koji su primljeni na našu kliniku iz drugih zdravstvenih centara.

Zaključak: Lekari bi trebalo da budu jako oprezni prilikom postavljanja dijagnoze JME i prisustvo mioklonije i absens napada bi trebalo ispitati kod svih pacijenata koji se javljaju lekaru zbog generalizovanih tonično-kloničnih napada starosti 8-20 godina.

Ključne reči: juvenična mioklonična epilepsija, dijagnoza, idiopatska generalizovana epilepsija.

10. Proposal for revised classification of epilepsies and epileptic syndromes. Commission on Classification and Terminology of the International League Against Epilepsy. Epilepsia. 1989; 30(4): 389-99.

11. Jallon P, Latour P. Epidemiology of idiopathic generalized epilepsies. Epilepsia 2005; 46(s9): 10-4.

12. Obeid T, Panayiotopoulos CP. Juvenile myoclonic epilepsy: A study in Saudi Arabia. Epilepsia. 1988; 29(3): 280-2.

13. Asadi-Pooya AA, Hashemzehi Z, Emami M. Epidemiology and clinical manifestations of juvenile myoclonic epilepsy (JME) in Iran. Neurol Sci. 2015; 36(5): 713-6.

14. Camfield CS, Striano P, Camfield PR. Epidemiology of juvenile myoclonic epilepsy. Epilepsy Behav. 2013; 28 (Suppl 1): S15-7.

15. Kishk N, Mourad H, Ibrahim S, Shamloul R, Al Azazi A, Shalaby N. Sex differences among epileptic patients: a comparison of epilepsy and its impacts on demographic features, clinical characteristics, and management patterns in a tertiary care hospital in Egypt. Egypt J Neurol Psychiatry Neurosurg. 2019; 55(1): 39.

16. Zhang Y, Chen J, Ren J, Liua W, Yanga T, Zhoua D. Clinical features and treatment outcomes of Juvenile myoclonic epilepsy patients. Epilepsia Open. 2019; 4(2): 302-8.

17. Abdalla SF, ELmagzoub MS, Albagi HA. Juvenile myoclonic epilepsy among Sudanese patients: prevelance and EEG characterizations. J Neurol Stroke. 2017; 6(4): 00207.

18. Seneviratne U, Cook M, D'Souza W. The electroencephalogram of idiopathic generalized epilepsy. Epilepsia. 2012; 53(2): 234-48. 
19. Shahnaz, Sher K, Abdul Sattar R. Clinical and EEG characteristics of juvenile myoclonic epilepsy. Pak J Med Sci. 2014; 30(1): 12-5.

20. Najafi MR, Najafi MA, Safaei A. Association of family history of epilepsy with earlier age onset of juvenile myoclonic epilepsy. Iran J Child Neurol. 2016; 10(2): 10-5.

21. Cacao G, Parra J, Mannan S, Sisodiya SM, Sander JW. Juvenile myoclonic epilepsy refractory to treatment in a tertiary referral center. Epilepsy Behav. 2018; 82: 81-6.

22. Chen Y, Chen J, Chen X, Wang R, Zeng J, Wang F, et al. Predictors of outcome in juvenile myoclonic epilepsy. Risk Manag Healthc Policy. 2020; 13: 609-13.
23. European Medicines Agency. CMDh agrees to strengthen warnings on the use of valproate medicines in women and girls. https://www.ema.europa.eu/en/ medicines/human/referrals/valproate-related-substances\#all-documents-section; 2014, Accessed date: 25 March 2019

24. Bosak M, S`owik A, Turaj W. Why do some women with epilepsy use valproic acid despite current guidelines? A single-center cohort study. Epilepsy Behav. 2019; 98(Pt A): $1-5$.

25. Genton P, Thomas P, Kasteleijn-Nolst Trenite DG, Medina MT, Salas-Puig J. Clinical aspects of juvenile myoclonic epilepsy. Epilepsy Behav. 2013; 28 (Suppl. 1): S8-S14.

\section{Correspondence to/Autor za korespondenciju}

Cemile Haki, MD

Department of Neurology, Bursa City Hospital, Bursa, Turkey

e-mail: cemilehaki@gmail

Adress: T.C. Sağlık Bakanlığı Bursa Şehir Hastanesi

Doğanköy Mahallesi, 16110 Nilüfer / BURSA

Telephone Number: 05324713151- 0 (224) 9750000

ORCID ID: 0000-0002-9679-8007 